\title{
IMPACTS OF COMPOST, BIOFERTILIZER AND/OR SOME ANTIOXIDANT TREATMENTS ON GLADIOLUS (GLADIOLUS GRANDIFLORAS) B. Corms and cormels production and some chemical constituents
}

Key words: Microbein biofertilizer, gladiolus, bulb production, antioxidants, chemical constituents.

\section{INTRODUCTION}

Gladiolus (Gladiolus grandiflorus, L.) plant is considered as one of the most important flowering bulbs grown in Egypt. Gladiolus is an important bulbous ornamental plant, perennial geophyte, semi- 


\section{A.A. Hassan and M.M. Abd El-Azeim}

rustice herbaceous annual bulbous plant belongs to the Iridaceae family and is used as cut flowers, garden and potted plants (Demir and Çelikel 2019). It is a monocotyledonous floral crop. There are fast expands in areas planted with gladiolus in Egypt in order to meet the increase demand for gladiolus flowers for local market and exporting, gladiolus plants propagated by corms. Gladiolus is a flower of glamour and perfection which is known as the queen of bulbous flowers due to its long spikes with florets of massive form, rich variations of colours, attractive shades, varying sizes of flowers and long vase life (Roy et al., 2017 and Rashid, 2018). Today gladiolus is one of the world's most important bulbous ornamental garden plant and as a cut flower crop used for bouquets and arrangements (Cantor and Tolety, 2011; Demir and Çelikel, 2019). In addition to their potential usage as ornamental plants, their usage in phytomedicine due to the medical properties of the modified stems, leaves and in other related industries increases their importance. In Egypt, the year-round production of cut flower crops is a nature's boon, due to the country has varied agro-climatic conditions. Different gladiolus varieties as cut flowers are important cut flower crops used in flower arrangements, in making bouquets, garden display and in beautifying any landscape (Abdou et al., 2019). However, various stress factors are associated with any flower crop that directly and indirectly hampers the growth of plant and results in poor quality flower, deprived yield and low income. Both higher and lower levels of abiotic stresses lead to decrease in flower quality and adversely affect corms and cormels production and the yield of gladiolus flowers (Sisodia et al., 2020).

Compost as organic fertilizer, Microbein biofertilizer (M.B.) and some antioxidant (salicylic and ascorbic acids) treatments are among the important agricultural treatments which have been proved to improve corm and cormels production of gladiolus plants. The effect of organic fertilization on increasing corm diameter, number of new cormels and dry weight of corm and cormels of gladiolus were reported by many investigators, such as Ahmed (2013), Abdou et al. (2018), Abdou et al. (2019) and Karagöz et al. (2019) on gladiolus, Kabir et al. (2011), Srivastava et al. (2014) and Suseela et al. (2016) on tuberose, Mirkalae et al. (2013) and Prasad et al. (2017) on lily, Pandey et al. (2017) on dahlia plant who found that compost fertilizer improved the chemical composition of gladiolus plants. Microbein biofertilizer (M.B.) treatments were found to have stimulating effect on corm and cormels production and chemical composition of gladiolus such as those raveled by Srivastava and Govil (2005), Kashyap (2016), Sathyanarayana et al. (2018) and Chakradhar et al. (2019) on gladiolus and Attia et al. (2018) on tuberose plant.

In regard to the roles of salicylic acid in increasing corm and cormels production, as well as, chemical constituents were mentioned by Pawar et al. (2018) and AlHasnawi et al. (2019) on gladiolus, Ahmad et al. (2018) on tuberose and Aashutosh et al. (2019) on chrysanthemum plant. Also, the role of ascorbic acid (vit. C) in improving on corm and cormels production and chemical composition was also investigated by Abdel Aziz et al. (2009) and Khalil (2015) on gladiolus, Mohammed et al. (2016) on dahlia plant and Farahat et al. (2017) on Monstera delicious plants.

The vegetative attributes, flower and corm production in gladiolus could be positively influenced by different organic fertilizers treatments when applied in optimum concentration (Abdou et al., 2019; Ahmed and Rab, 2019). Good quality corms result in better vegetative growth with healthy foliage and enhanced photosynthetic activity (Sarkar et al., 2014). Keeping in mind, the significant role of organic, biofertilizers and antioxidants in plants and its potential effects on vegetative traits and quality production of gladiolus corms, an experiment was conducted during seasons 2018/2019 and 2019/2020. 
This experiment was conducted to study effects of compost application, Microbein biofertilizer (M.B.) and/or spraying with some antioxidants (salicylic and ascorbic acids) treatments on corms and cormels production, as well as, chemical constituents of Gladiolus grandiflorus var. Jester plants.

\section{MATERIALS AND METHODS}

The present study was carried out at the Nursery and Laboratory of Ornamental plants, Faculty of Agriculture, Minia University during two successive seasons of 2018/2019 and 2019/2020 on gladiolus plants.

Gladiolus grandiflorus var. Jester corms were obtained from Holland by Basiony Nurseries, Cairo, Egypt. Average corm diameter was 2.6 and $3.2 \mathrm{~cm}$ and corms weight were 9.5 and $10.4 \mathrm{~g}$ for the first and second seasons, respectively. All corms were soaking for one minute in Pinilate (fungicide) at the concentration of $1 \mathrm{~g} / \mathrm{l}$ before planting in both successive experimental seasons. Corms were planted on October $1^{\text {st }}$ for both seasons in $1.5 \times 2.0$ $\mathrm{m}$ plots containing 3 ridges, $50 \mathrm{~cm}$ apart. Corms were planted in hills, $20 \mathrm{~cm}$ apart (10 corms/ridge) at a depth of $5 \mathrm{~cm}$ under ground surface in clay loam soil. The physical and chemical analysis of the used soil in both seasons were determined according to Jackson (1973) and Page et al. (1982) and shown in Table (1)

The split plot design with three replicates was followed in this experiment.
The four levels of compost fertilization treatments were considered as main plots and the seven treatments of Microbein biofertilizer (M.B.) and/or some antioxidants (salicylic acid and vitamin C) treatments as the sub plots. The four levels of compost treatments were $0,5,10$ and 15 ton/fed. The compost (plant residues) was obtained from Egypt company for circulate solid residues, at New El Minia city (organic Nile compost). The compost added during preparing the soil to cultivation in the two experimental seasons.

Physical and chemical properties of the used compost (organic Nile compost) are shown in Table (2).

Gladiolus plants were inoculated by Microbein biofertilizer (M.B.) at the rate of $50 \mathrm{ml} / \mathrm{hill}$, as well as, some antioxidants (salicylic and ascorbic acids) treatments both at the concentration of $50 \mathrm{ppm}$ were applied, by hand sprayer, 3 times, one month and two months from planting date and after flowers cut for corm and cormels production. The plants were sprayed till run off. All agricultural practices were performed as usual in the region.

The Microbein was obtained from laboratory of Biofertilizers, Department of Genetics, Fac. of Agric., Minia Univ. and Salicylic and ascorbic acids were obtained from Shoura Company.

\section{The following data were recorded:}

1. Underground parts characters at harvesting after the foliage had dried (the

Table 1. Some soil physiochemical properties of the investigated soil.

\begin{tabular}{|c|c|c|c|c|c|}
\hline \multicolumn{4}{|c|}{ Soil chemical properties } & \multicolumn{2}{|c|}{ Soil physical properties } \\
\hline Character & Value & Character & Value & Character & Value \\
\hline pH (1:2.5 water) & 7.7 & Total P ( g kg $\left.^{-1}\right)$ & 0.56 & F.C. \% & 42.45 \\
\hline $\mathrm{CaCO}_{3}\left(\mathrm{~g} \mathrm{~kg}^{-1}\right)$ & 17.9 & Available $\mathbf{P}\left(\mathrm{mg} \mathrm{kg}^{-1}\right)$ & 13.11 & PWP \% & 13.78 \\
\hline CEC $\left(\mathrm{cmol}_{\mathrm{c}} \mathrm{kg}^{-1}\right)$ & 37.87 & Total K (g kg-1) & 4.37 & WHC \% & 48.76 \\
\hline $\mathrm{EC}\left(\mathrm{dS} \mathrm{m} \mathrm{m}^{-1}\right.$ at $\left.25^{\circ} \mathrm{C}\right)$ & 1.35 & Exch. $\mathrm{K}^{+}$(mg/100 g soil) & 2.85 & A.V. (F.C. - PWP) \% & 28.67 \\
\hline OM (g kg-1) & 28.61 & Exch. Ca ${ }^{++}(\mathrm{mg} / 100$ g soil $)$ & 31.12 & A.V. (WHC-PWP) \% & 34.98 \\
\hline Total N (g kg-1) & 1.29 & Exch. $\mathrm{Mg}^{++}$(mg/100 g soil) & 8.77 & Bulk density (BD) $\mathrm{g} / \mathrm{cm}^{3}$ & 1.31 \\
\hline Total C/N ratio & 22.17 & Exch. $\mathrm{Na}^{+}$(mg/100 g soil) & 2.52 & Particle density (PD) g/ $\mathrm{cm}^{3}$ & 2.22 \\
\hline SOC $\left(\mathrm{g} \mathrm{kg}^{-1}\right)$ & 18.48 & DTPA Ext. (mg kg-1) Fe & 8.23 & Sand \% & 28.9 \\
\hline Organic $N\left(\mathrm{~g} \mathrm{~kg}^{-1}\right)$ & 0.76 & $\mathbf{C u}$ & 2.01 & Silt \% & 32.8 \\
\hline Organic $\mathrm{C} / \mathrm{N}$ ratio & 24.31 & Zn & 2.87 & Clay \% & 38.3 \\
\hline Mineral N (mg kg $\left.{ }^{-1}\right)$ & 58.46 & Mn & 8.11 & Soil texture & Clay loam \\
\hline
\end{tabular}




\section{A.A. Hassan and M.M. Abd El-Azeim}

Table 2. Nutrient composition and physicochemical properties for the investigated compost.

\begin{tabular}{|c|c|c|c|}
\hline Compost property & Value & Compost property & Value \\
\hline Dry weight of $1 \mathrm{~m}^{3}$ & $450 \mathrm{~kg}$ & $\mathrm{C} / \mathrm{N}$ ratio & 26.50 \\
\hline Fresh weight of $1 \mathbf{~ m}^{3}$ & $650-700 \mathrm{~kg}$ & $\mathbf{N} / \mathbf{P}$ ratio & 2.00 \\
\hline Moisture weight (\%) & $36.60 \%$ & Total P ( g kg $\left.^{-1}\right)$ (D.M.) & 5.0 \\
\hline pH (1:2.5) & 7.90 & Total K ( kg $\left.^{-1}\right)$ (D.M.) & 9.0 \\
\hline $\mathrm{EC}\left(\mathrm{ds} \mathrm{m^{-1 }}\right.$ at $\left.25 \mathrm{C}^{0}\right)$ & 2.20 & Total Ca $\left(\mathrm{g} \mathrm{kg}^{-1}\right)$ (D.M.) & 26.3 \\
\hline CEC $\left(\mathrm{cmol}_{+} \mathrm{kg}^{-1}\right)$ & 45.66 & Total Mg (g kg $\left.{ }^{-1}\right)$ (D.M.) & 6.6 \\
\hline Dry solids \% & 63.40 & $\operatorname{NaCl}(\%)$ & $0.72-0.75$ \\
\hline Ash \% & 9.90 & Fe $\left(\mathrm{mg} \mathrm{kg}^{-1}\right)$ & $150-200$ \\
\hline Total N (g kg-1) (D.M.) & 10.0 & $\operatorname{Mn}\left(\mathrm{mg} \mathrm{kg}^{-1}\right)$ & $25-56$ \\
\hline Total Organic Matter (\%) & $32-34 \%$ & $\mathrm{Cu}\left(\mathrm{mg} \mathrm{kg}^{-1}\right)$ & $75-150$ \\
\hline Total Organic carbon (\%) & $18.5-19.7 \%$ & $\mathrm{Zn}\left(\mathrm{mg} \mathrm{kg}^{-1}\right)$ & $150-225$ \\
\hline
\end{tabular}

underground parts were lifted 2 months after cut spikes): corm diameter $(\mathrm{cm})$, number of new cormels/plant and dry weights of corm and cormels (g).

2. Determination of some chemical constituents: fresh leaves samples were taken after 75 days from planting to determine chlorophyll a, b and carotenoids as (mg/g. F.W.) using the method described by Fadl and Sari ElDeen (1979). The percentages of N, P and $\mathrm{K}$ in the dry leaves were estimated according to the methods described by Wilde et al. (1985), Champan and Pratt (1975) and Cottenie et al. (1982), respectively. All obtained data were tabulated and statistically analyzed according to MSTAT-C (1986) and the L.S.D. test at $5 \%$ was followed to compare between the means.

\section{RESULTS AND DISCUSSION}

\section{Corms and cormels production:}

Data in Tables (3 and 4) indicated that corm diameter $(\mathrm{cm})$, corm dry weight $(\mathrm{g})$, number of cormels/plant and cormels dry weight (g) were significantly increased with increasing compost fertilizer levels, during both growing successive seasons, in comparison with control. The high level of compost (15 ton/fed) resulted in the highest values for all corm and cormels production traits. Similar results were investigated by Zaghloul and Moghazy (2001), Chandar et al. (2012), Abdou and Ibrahim (2015), Abdou et al. (2018) and Karagöz et al. (2019) on gladiolus, Abd El-Karim (2001), Abdel-Sattar et al. (2010), Srivastava et al. (2014) and Pattnaik (2016) on tuberose, ElNaggar and El-Nasharty (2009) on Hippeastrum vittatum, El-Sayed et al. (2012) on freesia and Prasad et al. (2017) on lily. The increase in corms and cormels production was attributed to the positive effect of organic fertilizers in improving the vegetative growth, as well as, stimulating chlorophyll (Mashali, 1997) which reflected on increasing the underground organs of gladiolus.

In relation to the sub-plot treatments, the seven tested ones surpassed, significantly at $5 \%$ level, the control treatment in both seasons in producing wider corm diameter, higher number of new cormels/plant and heavier dry weights of corm and cormels. Also, the use of three mixed Microbein biofertilizer (M.B.) plus salicylic acid plus vitamin $\mathrm{C}$ treatments were more effective than other treatments and resulted in the highest values in this concern. Similar observation was pointed out by Srivastava and Govil (2005), Sathyanarayana et al. (2018) and Chakradhar et al. (2019) on gladiolus and Khan et al. (2009) on tulip plant. 
Table 3. Effect of experimental treatments on corm diameter $(\mathrm{cm})$ and corm dry weight (g) of Gladiolus grandiflorus var. Jester during the first and second seasons.

\begin{tabular}{|c|c|c|c|c|c|c|c|c|c|c|}
\hline \multirow{3}{*}{ Treatments (B) } & \multicolumn{10}{|c|}{ Compost levels (ton/fed) (A) } \\
\hline & \multicolumn{5}{|c|}{$1^{\text {st }}$ season $(2018 / 2019)$} & \multicolumn{5}{|c|}{$2^{\text {nd }}$ season $(2019 / 2020)$} \\
\hline & $\mathbf{0}$ & 5 & 10 & 15 & $\begin{array}{c}\text { Mean } \\
\text { (B) }\end{array}$ & $\mathbf{0}$ & 5 & 10 & 15 & $\begin{array}{c}\text { Mean } \\
(\mathrm{B})\end{array}$ \\
\hline & \multicolumn{10}{|c|}{ Corm diameter $(\mathrm{cm})$} \\
\hline Control & 2.38 & 2.43 & 2.51 & 2.57 & 2.47 & 2.50 & 2.58 & 2.65 & 2.73 & 2.62 \\
\hline Salicylic acid (S.A.) & 2.67 & 2.75 & 2.84 & 2.92 & 2.80 & 3.82 & 3.93 & 4.05 & 4.18 & 4.00 \\
\hline Ascorbic acid (vit. C) & 2.86 & 2.95 & 3.03 & 3.13 & 2.99 & 4.03 & 4.15 & 4.28 & 4.40 & 4.22 \\
\hline Microbein biofertilizer & 3.05 & 3.12 & 3.21 & 3.01 & 3.10 & 4.24 & 4.37 & 4.50 & 4.63 & 4.44 \\
\hline Microbein + S.A. & 3.26 & 3.36 & 3.47 & 3.56 & 3.41 & 4.45 & 4.58 & 4.72 & 4.86 & 4.65 \\
\hline Microbein + vit. C & 3.47 & 3.58 & 3.68 & 3.79 & 3.63 & 4.64 & 4.77 & 4.92 & 5.07 & 4.85 \\
\hline Microbein + S.A. + vit. C & 3.68 & 3.79 & 3.91 & 4.04 & 3.86 & 4.83 & 4.97 & 5.12 & 5.27 & 5.05 \\
\hline Mean (A) & 3.05 & 3.14 & 3.24 & 3.29 & & 4.07 & 4.19 & 4.32 & 4.45 & \\
\hline \multirow[t]{2}{*}{ L.S.D. at $5 \%$} & \multicolumn{2}{|c|}{ A:0.04 } & B:0.07 & \multicolumn{2}{|c|}{ AB:0.14 } & \multicolumn{2}{|c|}{ A:0.05 } & 0.09 & \multicolumn{2}{|c|}{ AB:0.18 } \\
\hline & \multicolumn{10}{|c|}{ Corm dry weight (g) } \\
\hline Control & 26.00 & 27.40 & 28.12 & 29.25 & 27.69 & 28.50 & 29.64 & 30.83 & 32.06 & 30.26 \\
\hline Salicylic ac & 28.10 & 29.22 & 30.39 & 31.61 & 29.83 & 30.59 & 31.81 & 33.09 & 34.41 & 32.48 \\
\hline Ascorbic acid (vit. C) & 30.21 & 31.42 & 32.68 & 33.98 & 32.07 & 32.66 & 33.97 & 35.32 & 36.74 & 34.67 \\
\hline Microbein biofertilizer & 32.33 & 33.62 & 34.97 & 36.36 & 34.32 & 34.73 & 36.12 & 37.56 & 39.07 & 36.87 \\
\hline Microbein + S.A. & 34.44 & 35.82 & 37.25 & 38.74 & 36.56 & 36.84 & 38.31 & 39.85 & 41.44 & 39.11 \\
\hline Microbein + vit. C & 36.55 & 38.01 & 39.53 & 41.11 & 38.80 & 38.95 & 40.50 & 42.12 & 43.80 & 41.34 \\
\hline Microbein + S.A. + vit. C & 38.67 & 40.22 & 41.83 & 43.50 & 41.06 & 41.06 & 42.29 & 43.98 & 45.74 & 43.27 \\
\hline Mean (A) & 32.33 & 33.67 & 34.97 & 36.36 & & 34.76 & 36.09 & 37.54 & 39.04 & \\
\hline L.S.D. at $5 \%$ & \multicolumn{2}{|c|}{$\mathrm{A}: 1.25$} & B:1.50 & \multicolumn{2}{|c|}{ AB:3.00 } & \multicolumn{2}{|c|}{$\mathrm{A}: 1.30$} & B:1.65 & \multicolumn{2}{|c|}{$\mathrm{AB}: 3.30$} \\
\hline
\end{tabular}

Table 4. Effect of experimental treatments on number of new cormels and cormels dry weight (g) of Gladiolus grandiflorus var. Jester during the first and second seasons.

\begin{tabular}{|c|c|c|c|c|c|c|c|c|c|c|}
\hline \multirow{3}{*}{ Treatments (B) } & \multicolumn{10}{|c|}{ Compost levels (ton/fed) (A) } \\
\hline & \multicolumn{5}{|c|}{$1^{\text {st }}$ season $(2018 / 2019)$} & \multicolumn{5}{|c|}{$2^{\text {nd }}$ season $(2019 / 2020)$} \\
\hline & $\mathbf{0}$ & 5 & 10 & 15 & $\begin{array}{l}\text { Mean } \\
\text { (B) }\end{array}$ & $\mathbf{0}$ & 5 & 10 & 15 & $\begin{array}{c}\text { Mean } \\
\text { (B) }\end{array}$ \\
\hline & \multicolumn{10}{|c|}{ Number of new cormels } \\
\hline Control & 17.9 & 21.9 & 24.3 & 26.9 & 22.8 & 19.0 & 24.4 & 25.8 & 28.4 & 24.4 \\
\hline Salicylic acid (S.A.) & 20.8 & 25.0 & 27.4 & 29.8 & 25.8 & 22.1 & 27.5 & 28.9 & 31.5 & 27.5 \\
\hline Ascorbic acid (vit. C) & 23.3 & 27.5 & 29.9 & 32.3 & 28.3 & 24.2 & 29.7 & 30.9 & 33.5 & 29.6 \\
\hline Microbein biofertilizer & 26.4 & 30.6 & 32.9 & 35.4 & 31.3 & 25.7 & 31.2 & 32.4 & 35.0 & 31.1 \\
\hline Microbein + S.A. & 27.9 & 32.1 & 34.4 & 36.9 & 32.8 & 26.8 & 32.1 & 33.3 & 35.9 & 32.0 \\
\hline Microbein + vit. C & 28.2 & 33.4 & 35.7 & 37.2 & 33.6 & 28.3 & 33.6 & 34.8 & 37.4 & 33.5 \\
\hline Microbein + S.A. + vit. C & 30.3 & 35.5 & 37.9 & 42.7 & 36.6 & 31.4 & 36.7 & 37.9 & 41.5 & 36.9 \\
\hline Mean (A) & 25.0 & 29.4 & 31.8 & 34.5 & & 25.4 & 30.7 & 32.0 & 34.7 & \\
\hline \multirow[t]{2}{*}{ L.S.D. at $5 \%$} & \multicolumn{2}{|c|}{ A:0.9 } & B:0.7 & \multicolumn{2}{|c|}{ AB:1.4 } & \multicolumn{2}{|c|}{ A:1.2 } & B:0.9 & \multicolumn{2}{|c|}{ AB:0.18 } \\
\hline & \multicolumn{10}{|c|}{ Cormels dry weight (g) } \\
\hline Control & 8.95 & 11.10 & 12.15 & 13.40 & 11.40 & 9.50 & 12.20 & 12.90 & 14.20 & 12.20 \\
\hline Salicylic acid (S.A.) & 10.40 & 12.60 & 13.70 & 14.90 & 12.90 & 11.06 & 13.75 & 14.45 & 15.75 & 13.75 \\
\hline Ascorbic acid (vit. C) & 11.65 & 13.75 & 14.95 & 16.15 & 14.13 & 12.34 & 15.15 & 15.76 & 17.09 & 15.09 \\
\hline Microbein biofertilizer & 14.23 & 16.37 & 14.49 & 18.82 & 15.98 & 15.36 & 16.22 & 16.85 & 18.20 & 16.66 \\
\hline Microbein + S.A. & 14.51 & 16.69 & 17.89 & 19.19 & 17.07 & 14.50 & 17.01 & 17.65 & 19.03 & 17.05 \\
\hline Microbein + vit. C & 14.95 & 17.70 & 18.92 & 19.72 & 17.82 & 15.68 & 18.14 & 18.79 & 20.20 & 18.20 \\
\hline Microbein + S.A. + vit. C & 16.36 & 19.17 & 20.47 & 23.06 & 19.77 & 17.27 & 20.19 & 20.85 & 22.83 & 20.29 \\
\hline Mean (A) & 13.01 & 15.34 & 16.08 & 17.89 & & 13.67 & 16.09 & 16.75 & 18.19 & \\
\hline L.S.D. at $5 \%$ & \multicolumn{2}{|c|}{ A:0.61 } & B:0.31 & \multicolumn{2}{|c|}{ AB:0.62 } & \multicolumn{2}{|c|}{$\mathrm{A}: 0.65$} & B:0.38 & \multicolumn{2}{|c|}{$\mathrm{AB}: 0.76$} \\
\hline
\end{tabular}




\section{A.A. Hassan and M.M. Abd El-Azeim}

The stimulatory effect of the treatment of biofertilizer on corm and cormels production may be due to the mode of action of biofertilizers on the soil or plant, plant hormone, enzymes and vitamins which came from addition of biofertilizers, which gave better growth consequently increase in all corm and cormels production parameters (Sorial et al., 1992 and El-Haddad et al., 1993). The role of salicylic acid treatments in increasing corm and cormels parameters was mentioned by Pawar et al. (2018) and Al-Hasnawi et al. (2019) on gladiolus, Ramtin et al. (2016) on carnation, Fouda and El-Gazairly (2017) on canola, Amir et al. (2017) on zinnia, Ahmad et al. (2018) and Nassour et al. (2019) on tuberose plant. The role of ascorbic acid (vit. C) in improving corm and cormels traits was also discussed by Mehdikhah et al. (2016) on gerbera, Mohammed et al. (2016) on dahlia plant and Dalawai and Naif (2017) on Dianthus caryophyllus and Gaber (2019) on Pelargonium zonale plant.

The interaction between the main and sub plot treatments was significant, in both seasons, in regard to corm diameter $(\mathrm{cm})$, corm dry weight (g), number of new cormels/plant and cormels dry weight(g). In most case, the highest values were obtained for all corm and cormels production parameters when gladiolus plants received compost at 15 ton/fed in combination with Microbein biofertilizer (M.B.) plus salicylic acid plus vitamin $C$ followed by the high level of compost (15 ton/fed) with the two mixed of Microbein biofertilizer (M.B.) plus vitamin $C$ then the medium level of compost (10 ton/fed) with the three mixed of Microbein biofertilizer (M.B.) plus salicylic acid plus vitamin $\mathrm{C}$. The highest corm diameter $(5.27 \mathrm{~cm})$ was produced by plants received compost at 15 ton/fed in combination with Microbein biofertilizer (M.B.) plus salicylic acid plus vitamin C, while least size $(2.5 \mathrm{~cm})$ of corm was observed in control plants (Fig., 1). Size of corm affects the growth, floral and corm yield attributes in gladiolus. Smaller sizes of the corms are poor yielder and larger sized corms add in cost of cultivation (Rashid, 2018). Therefore, it is essential to find out optimum size of corms for obtaining the best results.

\section{Chemical constituents:}

\section{Photosynthetic pigments:}

The contents of chlorophyll a, b and carotenoids in the fresh leaves of Gladiolus grandiflorus var. Jester were significantly promoted due to compost level treatments, in both growing seasons, in comparison with those of untreated plants as shown in Table (5). The high level of compost (15 ton/fed) gave the highest values for the three photosynthetic pigments in both seasons. These results may be attributed to the increase in nutrient elements and/or positive role of organic fertilizer on the physical and chemical properties of the soil, that reflected on the growth and the pigments content. In harmony with these results regarding organic fertilization treatments were those mentioned by Abdou et al. (2013), Khalil (2015), Abdou et al. (2018) and Abdou et al. (2019) on gladiolus, El-Naggar and El-Nasharty (2009) on Hippeastrum vittatum and Dalawai and Naif (2017) on Dianthus caryophyllus.

In relation to the influence of Microbein biofertilizer (M.B.) and/or some antioxidant (salicylic acid and vitamin C) treatments on chlorophyll a, b and carotenoids contents were promoted, in both seasons (Table, 5). Using both Microbein biofertilizer (M.B.) and/or some antioxidant (salicylic acid and vitamin C) treatments together was more effective than the other used treatments. Also, differences between any treatment and control was statistically significant. Among the six treatments, the three mixed Microbein biofertilizer (M.B.) plus salicylic acid plus vitamin $C$ resulted the highest values over all other treatments. These results may be attributed not only to the increase in nutrient elements, but also to the role of Microbein biofertilizer (M.B.) treatment on stomatal regulation, photosynthesis and growth as indicated by 


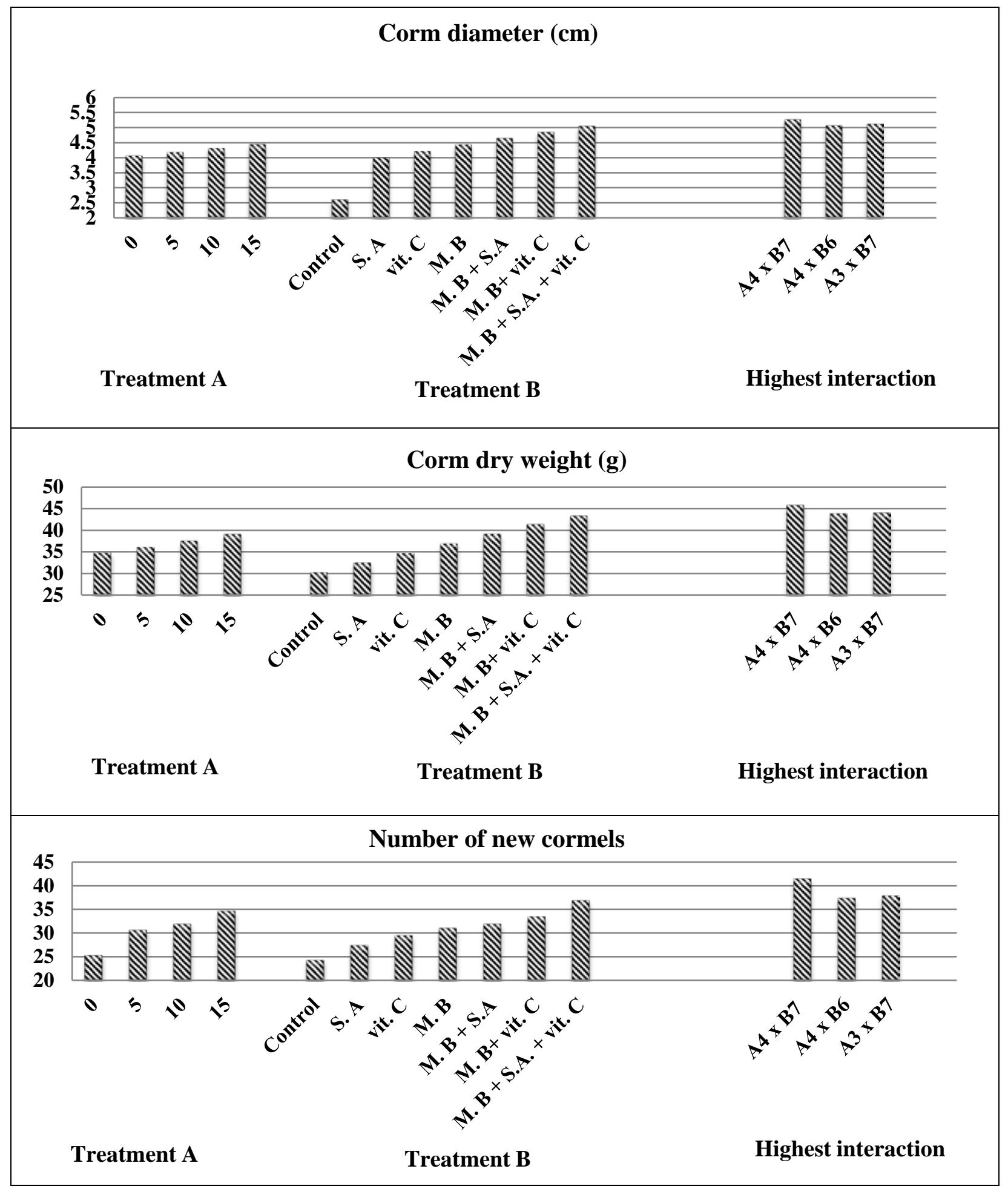

Fig. 1. Quality parameters of gladiolus (corm diameter $(\mathrm{cm})$, corm dry weight (g) and number of new cormels) as affected by experimental treatments, compost 15 ton/fed + M.B. + S.A. + V.C (A4 x B7); compost 15 ton/fed + M.B. + V.C (A4 x B6); compost 10ton/fed + M.B. + S.A. + V.C (A3 x B7). 


\section{A.A. Hassan and M.M. Abd El-Azeim}

Table 5. Effect of experimental treatments on photosynthetic pigments (mg/g F.W.) of Gladiolus grandiflorus var. Jester during the first and second seasons.

\begin{tabular}{|c|c|c|c|c|c|c|c|c|c|c|}
\hline \multirow{3}{*}{ Treatments (B) } & \multicolumn{10}{|c|}{ Compost levels (ton/fed) (A) } \\
\hline & \multicolumn{5}{|c|}{$1^{\text {st }}$ season $(2018 / 2019)$} & \multicolumn{5}{|c|}{$2^{\text {nd }}$ season $(2019 / 2020)$} \\
\hline & $\mathbf{0}$ & 5 & 10 & 15 & $\begin{array}{c}\text { Mean } \\
\text { (B) }\end{array}$ & $\mathbf{0}$ & 5 & 10 & 15 & $\begin{array}{c}\text { Mean } \\
\text { (B) }\end{array}$ \\
\hline & \multicolumn{10}{|c|}{ Chlorophyll a content (mg/g. F.W.) } \\
\hline Control & 2.335 & 2.374 & 2.380 & 2.415 & 2.376 & 2.364 & 2.403 & 2.409 & 2.445 & 2.405 \\
\hline Salicylic acid (S.A.) & 2.407 & 2.418 & 2.442 & 2.448 & 2.429 & 2.436 & 2.448 & 2.472 & 2.478 & 2.458 \\
\hline Ascorbic acid (vit. C) & 2.439 & 2.454 & 2.478 & 2.493 & 2.466 & 2.469 & 2.484 & 2.508 & 2.523 & 2.496 \\
\hline Microbein biofertilizer & 2.472 & 2.487 & 2.505 & 2.531 & 2.499 & 2.502 & 2.517 & 2.535 & 2.562 & 2.529 \\
\hline Microbein + S.A. & 2.499 & 2.510 & 2.537 & 2.567 & 2.528 & 2.529 & 2.541 & 2.568 & 2.598 & 2.559 \\
\hline Microbein + vit. C & 2.513 & 2.546 & 2.576 & 2.609 & 2.561 & 2.544 & 2.577 & 2.607 & 2.640 & 2.592 \\
\hline Microbein + S.A. + vit. C & 2.558 & 2.579 & 2.614 & 2.647 & 2.600 & 2.589 & 2.610 & 2.646 & 2.679 & 2.631 \\
\hline Mean (A) & 2.460 & 2.481 & 2.505 & 2.530 & & 2.490 & 2.511 & 2.535 & 2.561 & \\
\hline \multirow[t]{2}{*}{ L.S.D. at $5 \%$} & \multicolumn{2}{|c|}{ A:0.016 } & B:0.025 & \multicolumn{2}{|c|}{ AB:0.050 } & \multicolumn{2}{|c|}{ A:0.020 } & B:0.028 & \multicolumn{2}{|c|}{ AB:0.056 } \\
\hline & \multicolumn{10}{|c|}{ Chlorophyll b content (mg/g. F.W.) } \\
\hline Control & 0.778 & 0.791 & 0.793 & 0.805 & 0.792 & 0.788 & 0.801 & 0.803 & 0.815 & 0.801 \\
\hline Salicylic acid (S.A.) & 0.802 & 0.806 & 0.814 & 0.816 & 0.809 & 0.812 & 0.816 & 0.824 & 0.826 & 0.819 \\
\hline Ascorbic acid (vit. C) & 0.813 & 0.818 & 0.826 & 0.831 & 0.822 & 0.823 & 0.828 & 0.836 & 0.841 & 0.832 \\
\hline Microbein biofertilizer & 0.824 & 0.829 & 0.835 & 0.843 & 0.833 & 0.834 & 0.839 & 0.845 & 0.854 & 0.843 \\
\hline Microbein + S.A. & 0.833 & 0.837 & 0.845 & 0.855 & 0.842 & 0.843 & 0.847 & 0.856 & 0.866 & 0.853 \\
\hline Microbein + vit. C & 0.838 & 0.848 & 0.858 & 0.869 & 0.853 & 0.848 & 0.859 & 0.869 & 0.880 & 0.864 \\
\hline Microbein + S.A. + vit. C & 0.852 & 0.859 & 0.871 & 0.882 & 0.866 & 0.863 & 0.870 & 0.882 & 0.893 & 0.877 \\
\hline Mean (A) & 0.820 & 0.827 & 0.835 & 0.843 & & 0.830 & 0.837 & 0.845 & 0.853 & \\
\hline \multirow[t]{2}{*}{ L.S.D. at $5 \%$} & \multicolumn{2}{|c|}{ A:0.006 } & B:0.008 & \multicolumn{2}{|c|}{ AB:0.016 } & \multicolumn{2}{|c|}{ A:0.007 } & B:0.010 & \multicolumn{2}{|c|}{ AB:0.020 } \\
\hline & \multicolumn{10}{|c|}{ Carotenoids content (mg/g. F.W.) } \\
\hline Control & 0.942 & 0.957 & 0.960 & 0.974 & 0.958 & 0.953 & 0.969 & 0.971 & 0.986 & 0.970 \\
\hline Salicylic ac & 0.970 & 0.975 & 0.985 & 0.987 & 0.979 & 0.982 & 0.987 & 0.997 & 0.999 & 0.991 \\
\hline Ascorbic acid (vit. C) & 0.983 & 0.989 & 0.999 & 1.005 & 0.994 & 0.995 & 1.002 & 1.011 & 1.017 & 1.006 \\
\hline Microbein biofertilizer & 0.997 & 1.003 & 1.010 & 1.021 & 1.007 & 1.009 & 1.015 & 1.022 & 1.033 & 1.020 \\
\hline Microbein + S.A. & 1.007 & 1.012 & 1.023 & 1.035 & 1.019 & 1.020 & 1.025 & 1.035 & 1.048 & 1.032 \\
\hline Microbein + vit. C & 1.013 & 1.027 & 1.039 & 1.052 & 1.033 & 1.026 & 1.039 & 1.051 & 1.065 & 1.045 \\
\hline Microbein + S.A. + vit. C & 1.031 & 1.040 & 1.054 & 1.067 & 1.048 & 1.044 & 1.052 & 1.067 & 1.080 & 1.061 \\
\hline Mean (A) & 0.992 & 1.000 & 1.010 & 1.020 & & 1.004 & 1.013 & 1.022 & 1.033 & \\
\hline L.S.D. at $5 \%$ & \multicolumn{2}{|c|}{ A:0.006 } & B:0.009 & \multicolumn{2}{|c|}{ AB:0.0018 } & \multicolumn{2}{|c|}{ A:0.008 } & B:0.012 & \multicolumn{2}{|c|}{ AB:0.024 } \\
\hline
\end{tabular}

Taha and Hassan (2008) on gladiolus and Attia et al. (2018) on tuberose. Also, salicylic acid increased pigments as reported by Pawar et al. (2018) and Al-Hasnawi et al. (2019) on gladiolus, Ramtin et al. (2016) on carnation and Nassour et al. (2019) on tuberose plant. Vitamin $\mathrm{C}$ gave the same results as obtained by Abdel Aziz et al. (2009) and Abo Leila and Eid (2011) on gladiolus, Abd El-Aziz et al. (2007) on syngonium, Kasim and Adil (2014) on freesia, Nikee et al. (2014) on summer savory, Mohammed et al. (2016) on dahlia and Gaber (2019) on Pelargonium zonale plant.

Effect of the interactions between compost, Microbein biofertilizer (M.B.) and/or some antioxidant (salicylic acid and vitamin C) treatments was significant in both seasons, for the photosynthetic pigments with the highest values being obtained due to the use of compost at 15 ton/fed in combination Microbein biofertilizer (M.B.) plus salicylic acid plus vitamin $C$ followed by 15 ton/fed compost with M.B. + vit. C then 10 ton/fed with M.B. + salicylic acid + 
vit. C, in most cases as shown in Table (5). Chlorophyll a and b are very important pigmented compounds in autotrophic plants, required for the process of photosynthesis by capturing photosynthetically active radiations (PAR) for plant growth and development (Saeed et al., 2013). The influence of compost application may be attributed to the increased vegetative as well as the chlorophyll content, and hence increased photosynthesis. It is likely to assume greater allocation of photosynthates to the daughter corms, that resulted in corms with larger size (Reddy and Sarkar, 2016).

\section{Nitrogen, phosphorus and potassium percentages:}

In both seasons, increasing the level of compost linearly increased the percentages of $\mathrm{N}, \mathrm{P}$ and $\mathrm{K}$ in the dry leaves. In this concern, the treatment with high level of compost (15 ton/fed) gave the highest percentages (Table, 6). On the other hand, the lowest values of $\mathrm{N}, \mathrm{P}$ and $\mathrm{K}$ percentages in the dry leaves of gladiolus were recorded by the control plants. Moreover, significant differences were detected between compost treatments and control one, also between compost treatments in all cases. The results mentioned above, could be attributed to that application of organic fertilizer improved soil properties, increase nutrients in area of roots, which increase nutrients uptake which in turn reflects on the corm quality.

These results are in agreement with those obtained by Sönmez et al. (2013), Khalil (2015), Abdou et al. (2018) on gladiolus, Abd El-Karim (2001) and Suseela et al. (2016) on tuberose, Eliwa et al. (2009) on Iris, El-Sayed et al. (2012) on freesia and Dalawai and Naif (2017) on Dianthus caryophyllus.

The percentages of $\mathrm{N}, \mathrm{P}$ and $\mathrm{K}$ were significantly increased, in both seasons, as a result of inoculating gladiolus with Microbein biofertilizer (M.B.) and spraying gladiolus with some antioxidant (salicylic acid and vitamin C) treatments in comparison with the control (Table, 6). The treatment of M.B. + salicylic acid + vit. C recorded the highest values for $\mathrm{N}, \mathrm{P}$ and $\mathrm{K} \%$ in both seasons. $\mathrm{N}$ - fixing bacteria enhance the uptake of different nutrients (Sorial et al., 1992). Also, salicylic acid is involved in a wide range of important functions as antioxidant defense and leaf development which increased photosynthetic rate (Jacquot et al., 2002). Ascorbic acid promoted nutrient elements uptake (Havaux et al., 2000). This positive effect of the used treatments led to promoted nutrient uptake and finally reflexes on the percentages of $\mathrm{N}$, $\mathrm{P}$ and $\mathrm{K}$.

The role of biofertilizer in improving $\mathrm{N}$, $\mathrm{P}$ and $\mathrm{K} \%$, which is in harmony with the obtained results was stated by Hassanein and El-Sayed (2009), and Sathyanarayana et al. (2018) on gladiolus, Abdou (2004) on dahlia, and Parmar et al. (2017) on Golden rod, Attia et al. (2018) on tuberose. Also, salicylic acid increased $\mathrm{N}, \mathrm{P}$ and $\mathrm{K} \%$ as revealed by Pal et al. (2015), Pawar et al. (2018) and Al-Hasnawi et al. (2019) on gladiolus, Mohamed (2017) on Aster, Ahmad et al. (2018) and Nassour et al. (2019) on tuberose plant. Vitamin C made the same trend to increase these characters was mentioned by Abdel Aziz et al. (2009) and Abo Leila and Eid (2011) on gladiolus, Abd El-Aziz et al. (2007) on syngonium, Abdou and Mohamed (2014) on mint and Mohammed et al. (2016) on dahlia plant.

Effect of the interaction treatments was significant, in both seasons, for $\mathrm{N}$ and $\mathrm{P} \%$ only. The highest values were obtained with the interaction treatments of 15 ton/fed compost in combination with M.B. plus salicylic acid plus ascorbic acid as shown in Table (6). Gladiolus is commercially propagated and grown from its specialized underground structure for production of flowers and corm as well as cormels (Adkins and Miller, 2008). Usually one daughter corm (new corm) along a number of cormels is produced (depending upon the size of daughter corm) in one season. 


\section{A.A. Hassan and M.M. Abd El-Azeim}

Table 6. Effect of experimental treatments on $\mathrm{N}, \mathrm{P}$ and $\mathrm{K}$ percentages in the dry leaves of Gladiolus grandiflorus var. Jester during the first and second seasons.

\begin{tabular}{|c|c|c|c|c|c|c|c|c|c|c|}
\hline \multirow{3}{*}{ Treatments (B) } & \multicolumn{10}{|c|}{ Compost levels (ton/fed) (A) } \\
\hline & \multicolumn{5}{|c|}{$1^{\text {st }}$ season $(2018 / 2019)$} & \multicolumn{5}{|c|}{$2^{\text {nd }}$ season $(2019 / 2020)$} \\
\hline & $\mathbf{0}$ & 5 & 10 & 15 & $\begin{array}{c}\text { Mean } \\
\text { (B) }\end{array}$ & $\mathbf{0}$ & 5 & 10 & 15 & $\begin{array}{c}\text { Mean } \\
\text { (B) }\end{array}$ \\
\hline & \multicolumn{10}{|c|}{ N \% } \\
\hline Control & 1.627 & 1.699 & 1.729 & 1.791 & 1.711 & 1.647 & 1.719 & 1.750 & 1.813 & 1.732 \\
\hline Salicylic acid (S.A.) & 1.757 & 1.803 & 1.876 & 1.936 & 1.843 & 1.778 & 1.825 & 1.899 & 1.960 & 1.865 \\
\hline Ascorbic acid (vit. C) & 1.822 & 1.977 & 2.071 & 2.093 & 1.991 & 1.845 & 2.001 & 2.096 & 2.119 & 2.015 \\
\hline Microbein biofertilizer & 2.028 & 2.085 & 2.145 & 2.228 & 2.121 & 2.052 & 2.111 & 2.171 & 2.255 & 2.147 \\
\hline Microbein + S.A. & 2.113 & 2.196 & 2.255 & 2.293 & 2.214 & 2.139 & 2.223 & 2.282 & 2.321 & 2.241 \\
\hline Microbein + vit. C & 2.198 & 2.261 & 2.297 & 2.368 & 2.281 & 2.225 & 2.289 & 2.325 & 2.397 & 2.309 \\
\hline Microbein + S.A. + vit. C & 2.273 & 2.344 & 2.371 & 2.391 & 2.345 & 2.301 & 2.372 & 2.400 & 2.420 & 2.374 \\
\hline Mean (A) & 1.974 & 2.052 & 2.106 & 2.157 & & 1.998 & 2.077 & 2.132 & 2.184 & \\
\hline \multirow[t]{2}{*}{ L.S.D. at $5 \%$} & \multicolumn{2}{|c|}{ A: 0.048} & B:0.021 & \multicolumn{2}{|c|}{ AB:0.042 } & \multicolumn{2}{|c|}{ A:0.051 } & B:0.024 & \multicolumn{2}{|c|}{ AB:0.048 } \\
\hline & \multicolumn{10}{|c|}{$\mathbf{P} \%$} \\
\hline Control & 0.222 & 0.233 & 0.253 & 0.292 & 0.250 & 0.225 & 0.236 & 0.256 & 0.296 & 0.253 \\
\hline Salicylic acid (S.A.) & 0.267 & 0.295 & 0.303 & 0.305 & 0.293 & 0.270 & 0.299 & 0.307 & 0.309 & 0.296 \\
\hline Ascorbic acid (vit. C) & 0.296 & 0.321 & 0.335 & 0.339 & 0.323 & 0.300 & 0.325 & 0.339 & 0.343 & 0.327 \\
\hline Microbein biofertilizer & 0.323 & 0.338 & 0.359 & 0.366 & 0.346 & 0.327 & 0.342 & 0.363 & 0.370 & 0.351 \\
\hline Microbein + S.A. & 0.350 & 0.361 & 0.371 & 0.386 & 0.367 & 0.354 & 0.365 & 0.375 & 0.391 & 0.371 \\
\hline Microbein + vit. C & 0.364 & 0.376 & 0.391 & 0.406 & 0.384 & 0.368 & 0.380 & 0.396 & 0.411 & 0.389 \\
\hline Microbein + S.A. + vit. C & 0.377 & 0.401 & 0.408 & 0.414 & 0.400 & 0.382 & 0.406 & 0.413 & 0.419 & 0.405 \\
\hline Mean (A) & 0.314 & 0.332 & 0.346 & 0.358 & & 0.318 & 0.336 & 0.350 & 0.363 & \\
\hline \multirow[t]{2}{*}{ L.S.D. at $5 \%$} & \multicolumn{2}{|c|}{ A:0.010 } & B:0.005 & \multicolumn{2}{|c|}{ AB:0.010 } & \multicolumn{2}{|c|}{ A:0.012 } & B:0.006 & \multicolumn{2}{|c|}{ AB:0.012 } \\
\hline & \multicolumn{10}{|c|}{ K \% } \\
\hline Control & 1.528 & 1.537 & 1.546 & 1.555 & 1.542 & 1.547 & 1.556 & 1.565 & 1.574 & 1.561 \\
\hline Salicylic acid (S.A.) & 1.548 & 1.562 & 1.568 & 1.571 & 1.562 & 1.567 & 1.581 & 1.587 & 1.590 & 1.581 \\
\hline Ascorbic acid (vit. C) & 1.566 & 1.573 & 1.582 & 1.593 & 1.579 & 1.585 & 1.592 & 1.601 & 1.612 & 1.598 \\
\hline Microbein biofertilizer & 1.580 & 1.589 & 1.596 & 1.616 & 1.595 & 1.600 & 1.608 & 1.615 & 1.636 & 1.615 \\
\hline Microbein + S.A. & 1.594 & 1.597 & 1.621 & 1.632 & 1.611 & 1.613 & 1.617 & 1.641 & 1.652 & 1.631 \\
\hline Microbein + vit. C & 1.611 & 1.622 & 1.637 & 1.643 & 1.628 & 1.631 & 1.642 & 1.657 & 1.663 & 1.648 \\
\hline Microbein + S.A. + vit. C & 1.625 & 1.641 & 1.648 & 1.652 & 1.642 & 1.645 & 1.661 & 1.668 & 1.672 & 1.662 \\
\hline Mean (A) & 1.579 & 1.589 & 1.600 & 1.609 & & 1.598 & 1.608 & 1.619 & 1.628 & \\
\hline L.S.D. at $5 \%$ & \multicolumn{2}{|c|}{ A:0.007 } & B:0.003 & \multicolumn{2}{|c|}{ AB:0.006 } & \multicolumn{2}{|c|}{ A:0.009 } & B:0.004 & \multicolumn{2}{|c|}{ AB: 0.008} \\
\hline
\end{tabular}

The daughter corm produces flowering spike in the same season whereas the cormels needs 2-4 seasons in order to get the reasonable size and produce marketable spikes (Memon et al., 2009). The corms and cormels of gladiolus remain dormant for 4-5 months with slight variations depending upon the cultivars and growing conditions (Priyakumari and Sheela, 2005). Production of both, flowering spikes and corms depends upon the size of mother corm and or cormels (Bose et al., 2003; Chourasia et al., 2015). Therefore, the vegetative characteristics, flower and corm production in gladiolus could be absolutely affected by different organic and bio-fertilizers in combination with antioxidants treatments when applied in optimal concentration (Abdou et al., 2019). Good quality corms give rise to better vegetative growth with healthy verdure and boosted photosynthetic activity (Sarkar et al., 2014; Ahmed and Rab, 2019). From the above results, it can be concluded that in respect of cultivation of gladiolus, applying of compost at the rate of 15 ton/fed in combination with Microbein biofertilizer 
(M.B.) plus salicylic acid plus vitamin $\mathrm{C}$ was most effective treatment for enhancing corms and cormels quality and chemical constituents of gladiolus.

\section{CONCLUSION}

Gladiolus is the second most important flower cut in Egypt after roses, with good export earnings potential. Gladiolus has a wide range of varieties and flowers available in various colors, shapes, and sizes. Besides its cut flowers, gladiolus is also planted in flower beds in landscape gardening and is used as specimen plant in flower shows and exhibitions. Results of this research indicated that the statistical analysis revealed significant differences in in the studied parameters in response to fertilization by compost in combination with Microbein biofertilizer (M.B.) and/or some antioxidants (salicylic and ascorbic acids) and the interaction of both factors was also significant. Plants of gladiolus treated with compost at the rate of 15 ton/fed in combination with Microbein biofertilizer (M.B.) plus salicylic acid plus vitamin C resulted in largest corm diameter $(\mathrm{cm})$, corm dry weight (g), number of cormels/plant and cormels dry weight (g), highest leaf chlorophyll a and b content, carotenoids and percentages of $\mathrm{N}, \mathrm{P}$ and $\mathrm{K}$ in the dry leaves. Good quality corms give rise to better vegetative growth with healthy flowers and boosted healthy plants verdure.

\section{REFERENCES}

Aashutosh, M.K.; Malik, S.; Singh, M.K.; Singh, S.P.; Chaudhary, V. and Sharma, V.R. (2019). Optimization of spacing, doses of vermi-compost and foliar application of salicylic acid on growth, flowering and soil health of chrysanthemum (Dendranthema grandiflora, Tzvelev) cv. "Guldasta”. International J. of Agric., Environ. and Biotech., 12(3):213-224.

Abd El-Aziz, N.G.; El-Quesni, F.E. and Farahat, M.M (2007). Response of vegetative growth and some chemical constituents of Syngonium podophyllum, L. to foliar application of thiamine, ascorbic acid and kinetin at Nubaria. World J. of Agric. Sci., 3 (3):301-305.

Abd El-Karim, F.M. (2001). . Ph.D. Thesis, Fac. Agric., Kafr El-Sheikh, Tanta Univ., Egypt, 132 p.

Abdel Aziz, G.N.; Taha, L. and Ibrahim, S.M.M. (2009). Some studies on the effect of putrescine, ascorbic acid and thiamine on growth, flowering and some chemical constituents of gladiolus at Nubaria. Ozean J. of Applied Sci., 2(2): 169-179.

Abdel-Sattar, M.M.; Ahmed, S.S. and Nabih, A. (2010). Response of tuberose (Polianthus tuberosa, L.) plant to different soil mixtures and Ethephon under reclaimed desert soil. Egypt. J. Biotechnol., 35:185-206.

Abdou, M.A.H and Mohamed, M.A.H. (2014). Effect of plant compost, salicylic and ascorbic acids on Mentha piperita, L. plants. Biological Agriculture and Horticulture Journal, 30(2):131-143.

Abdou, M.A.H. (2004). Physiological studies on dahlia II-: Effect of chemical and biofertilization treatments of Dahlia pinnata, Dahl. cv. Moonlight Sonata plants grown in sandy calcareous soil. Minia J. of Agric. Res. and Develop., 24(3): 437-456.

Abdou, M.A.H. and Ibrahim, T.I.E. (2015). Response of gladiolus cV. Carmen to compost, biofertilization and some vitamin treatments. Proc. of the $1^{\text {st }}$ Conf. of SSFOP, Scientific J. Flowers \& Ornamental Plants, 2(1):1-10.

Abdou, M.A.H.; Aly, M.K. and Ahmed, A.S.A. (2013). Effect of compost, biofertilization and some vitamins addition on Gladiolus grandiflorus. J. Plant Production, Mansoura Univ., 4(12): 1751-1761.

Abdou, M.A.H.; Aly, M.K. and Ahmed, A.S.A. (2019). Influence of organic 


\section{A.A. Hassan and M.M. Abd El-Azeim}

manure, biofertilizer and/or some vitamin treatments on: A. Vegetative growth and flowering aspects of Gladiolus grandiflorus var. Gold field plants. Scientific J. Flowers \& Ornamental Plants, 6(2):113-124.

Abdou, M.A.H.; Badran, F.S.; Ahmed, E.T.; Taha, R.A. and Abdel-Mola, M.A.M. (2018). Effect of compost and some natural stimulant treatments on: II. Corms production and chemical constituents of (Gladiolus grandiflorus cv. Peter Pears) plants. Proc. of The $4^{\text {th }}$ Conf. of SSFOP, Scientific J. Flowers \& Ornamental Plants, 5(2):115-126.

Abo Leila, B. and Eid, R. (2011). Improving gladiolus growth, flower keeping quality by using some vitamins application. Journal of American Science, 7(3):169174.

Adkins, J.A. and Miller, W.B. (2008). Storage organs. In: Beyl, C.A. and Trigiano, R.N. (eds), Plant Propagation: Concepts and Laboratory Exercises, Taylor \& Francis, Florida, USA, pp. 343348.

Ahmad, M.; Faiz, P.; Haq, S.I.; Nawaz, A.; Washa, P. and Ullah, Z. (2018). Foliar application of salicylic acid enhanced the production of tuberose (Polianthes tuberosa, L.). International J. of Agric. and Environ. Res., 4(4):191-197.

Ahmed, A.S.A. (2013). Physiological Studies on Gladiolus Plant. M.Sc. Thesis, Fac. Agric. Minia Univ. Egypt, 188 p.

Ahmed, M. and Rab, A. (2019). Exogenous application of calcium improved the vegetative attributes and corm production in gladiolus. Sarhad Journal of Agriculture, 35(3):1011-1019.

Al-Hasnawi, H.A.; Hussein, J.K. and Khaleel, T.H. (2019). Effect of growth regulators and preservative solution on vase life and water relation of Gladiolus hybrid, L. after cut flowers. Iraqi Journal of Agricultural Sciences, 50:182-191.
Amir, Z.; Ullah, F.; Syeda, E.; Gul, L.; Maaz, K.; Muhammad, Z.N.; Khan, and Amin, N. (2017). Influence of salicylic acid on growth and flowering of Znnia cultivars. Sci. Int. (Lahre), 29(6):13291335.

Attia, K.E.; Elbohy, N.F.S. and Ashour, N.A.M. (2018). Response of tuberose plants (Polianthes tuberosa. L.) to chemical and bio fertilization and their effect on vegetative growth, flowering and chemical composition under sandy soil conditions. Scientific J. Flowers \& Ornamental Plants, 5(3):261-273.

Bose, T.K.; Yadav, L.P. Pal, P. Das, P. and Parthasarathy, V.A. (2003). Commercial flowers, Volume II. Naya Udyog, Kolkata, India, 660 p.

Cantor, M. and Tolety, J. (2011). Gladiolus. In: Kole, C. (ed.), Wild Crop Relatives: Genomic and Breeding Resources, Plantation and Ornamental Crops. Springer, Berlin, Heidelberg, 303 p.

Chakradhar, P.; Bohra, M.; Goutham, K. B. K. and Upadhyay, S. (2019). Response of biofertilizers on floral and yield attributing parameters of gladiolus (Gladiolus grandiflorus, L.) var. Arka Amar under hill conditions of Uttarakhand. Int. J. Pure App. Biosci. 7(1): 157-161.

Champan, H.D. and Pratt, P.F. (1975). Methods of Analysis for Soil, Plant and Water. Calif. Univ. Division of Agric. Sci., 172-174.

Chandar, I.; Rawat, I.; Lakhawat, S.S. and Yadav, K.K. (2012). Effect of organic manures and biofertilizers on the yield parameters of Gladiolus cv. White Prosperity. Ecol., Environ. and Conservation Paper, 18(1): 91-94.

Chourasia, A.N.K.I.T.; Viradi, R.R.; Ansar, H. and Madle, S.N. (2015). Evaluation of different gladiolus cultivars for growth, flowering, spike yield and corm yield under Saurashtra region of Gujarat. Bioscan., 10(1):131-134. 
Cottenie, A.; Verloo, M.; Velghe, M. and Camerlynck, R. (1982). Chemical Analysis of Plant and Soil. Laboratory of Analytical and Agro Chemistry, State Univ., Ghent, Belgium, pp. 44-45.

Dalawai, B. and Naif, B.H. (2017). Influence of nutrient sources on performance of carnation (Dianthus caryophyllus, L.) cv. Soto under naturally ventilated polyhouse. Journal of Pharmacognosy and Phytochemistry, 6(5):2049-2051.

Demir, S. and Gelikel, F. G. (2019). Endangered gladiolus species of Turkey. Turkish Journal of Agriculture-Food Science and Technology, 7(5):693-697.

El-Haddad, M.E.; Ishac, Y.Z. and Mostafa, M.I. (1993). The role of bio-fertilizers in reducing agricultural costs, decreasing environment pollution and raising crop yield. Arab Univ. J. Agric. Sci., Ain Shams Univ., 1(1):147-159.

Eliwa, N.Y.; Rezk, B.B. and El-Shamy, M.A. (2009). Effect of organic and biofertilizer treatments on growth, flowering, bulbs production and chemical constituents of Iris tingitana cv. Wedgewood. J. Biol. Chem. Environ. Sci., 4: 441-461.

El-Naggar, A.H. and El-Nasharty, A.B. (2009). Effect of growing media and mineral fertilization on growth, flowering, bulbs productivity and chemical constituents of Hippeatrum vittatum, Herb. American-Eurasian J. Agric. and Enviro. Sci., 6(3): 360-371.

El-Sayed, A.; El-Hanafy, H.; Nabih, A. and Atowa, D.I. (2012). Raising Freesia refracta cv. Red Lion corms from cormels in response to different growing media and actosol levels. J. of Hort. Sci. Ornamental plants, 4(1): 89-97.

Fadl, M.S. and Sari El-Deen, S.A. (1979). Effect of N6-benzyladenine photosynthetic pigments and total sugars of olive seedlings grown under saline condition. Egypt. J. Hort., 6(2):169-183.
Farahat, M.M.; Abdel Aziz, N.G.; Hashish, K.I. and Mazhar, A.A.M. (2017). Effect of ascorbic acid on growth and chemical constituents of Monstera delicious under lead pollutant conditions. Agricultural Engineering International Journal, 1(1):239-244.

Fouda, H.M. and El-Gazairly, A.Y. (2017). Growth, yield and some physiological aspects of Canola (Brassica napus, L.) plants in response to treatment with gibberellic acid, vitamin $\mathrm{C}$ and zinc sulphate. International Journal of Innovative Science, Engineering \& Technology, 4(7):316-342.

Gaber, K.M. (2019). Vegetative and flowering growth of geranium as affected by mineral fertilization and ascorbic acid foliar application. Middle East J. Appl. Sci., 9(1):220-230.

Hassanein, M. M. and El-Sayed, S.G. (2009). Effect of some organic and biofertilization treatments on gladiolus plants: 2-Corm production and chemical constituents. J. Agric. Sci. Mansoura Univ., 34(6):6255-6268.

Havaux, M.; Bonfils, J.; Lutz, C. and Niyogi, K. (2000). Photodamage of the photosynthetic apparatus and its dependence on the leaf developmental stage in the Arabidopsis mutant deficient in the xanthophylls cycle enzyme violaxanthin de-epoxidase. Plant Physiol., 1124: 273-284.

Jackson, M.L. (1973). Soil Chemical Analysis Englewood Cliffs., New Prentice-Hall INC., New York, 498 p.

Jacquot, J.P.; Gelhaye, E.; Rouhier, N.; Corbier, C.; Didierjean, C. and Aubry, A. (2002). Thioredoxins and related proteins in photosynthetic organisms: molecular basis for thiol dependent regulation. Biochem. Pharm., 64:1065-1069.

Kabir, A.K.M.R.; Iman, M.H.; Mondal, M.M.A. and Chowdhury, S. (2011). Response of tuberose to integrated 


\section{A.A. Hassan and M.M. Abd El-Azeim}

nutrient management. J. Environ. Sci. \& Natural Resources, 4(2):55-59.

Karagöz, F.P.; Dursun, A.; Tekiner, N.; Kul, R. and Kotan, R. (2019). Efficacy of vermicompost and/or plant growth promoting bacteria on the plant growth and development in gladiolus. Ornamental Horticulture Journal, 25, (2): 180-188.

Kashyap, S.K. (2016). Effect of Biofertilizers with Different Levels of Nitrogen and Phosphorus on Growth and Flower Yield of Gladiolus (Gladiolus grandiflorus, L.). M.Sc. Thesis, College of Agric., Indira Gandhi Agricultural University, India, 74 p.

Kasim, J.Y. and Adil, A.M. (2014). Effect of gibberellic acid, spraying micronutrient and ascorbic acid in the vegetative growth, flowering of Freesia hybrida cv. Prominence. Journal of Kirkuk University for Agricultural Sciences, 5(1):50-64.

Khalil, A.R.M. (2015). Physiological Studies on Gladiolus Plant. M.Sc. Thesis, Fac. Agric. Minia Univ., 146 p.

Khan, F.U.; Saddique, M.A.A.; Khan, F.A. and Nazki, I.I. (2009). Effect of biofertilizers on growth, flower quality and bulb yield in tulip (Tulipa gesneriana). Indian J. of Agric. Sci., 79(4):248-251.

Mashali, A.M. (1997). FAO global network on integrated soil management for sustainable use of salt affected soils. Proceedings of International Symposium on Sustainable Management of Salt Affected Soils in the Arid Ecosystem. 2126 September, Cairo, Egypt; 31-51.

Mehdikhah, M.; Onsinejad, R.; Ilkaee, M.N. and Kaviani, B. (2016). Effect of salicylic acid, citric acid and ascorbic acid on post-harvest quality and vase life of gerbera (Gerbera jamesonii) cut flowers. Journal of Ornamental Plants, 6(3):181-191.
Memon, N.; Qasim, M.; Jaskani, M.J.; Ahmad, R. and Ahmad, I. (2009). Enhancement of corm and cormel production in gladiolus (Gladiolus spp.). New Zealand J. of Crop and Hort. Sci., 37(4): 319-325.

Mirkalae, S.M.; Ardebili, Z.O. and Mostafavi, M. (2013). The effects of different organic fertilization on the growth of Lilium longiflorum. Inter. Res. J. of Applied and Basic Sci., 4(1):181186.

Mohamed, Y.F.Y. (2017). Effect of some growth stimulants on growth, flowering and postharvest quality of Aster (Symphyotrichum novi-belgii, L.) cv. Purple Monarch. Middle East J. Agric. Res., 6(2):264-273.

Mohammed, S.A.; Abd-Allatif, S.A. and Obaid, A.A. (2016). Effect of foliar application with potassium sulphate and ascorbic acid on growth and flowering of dahlia (Dahlia variabilis, L. cv. Arizona). Diyala for Agricultural Sciences Journal, 8(1):232-248.

MSTAT-C (1986). A Microcomputer Program for the Design Management and Analysis of Agronomic Research Experiments (Version 4.0), Michigan State Univ., U.S.A.

Nassour, M.; Haifa, S. and Ahmad, N. (2019). Effect of humic and salicylic acids on growth, flowering and bulb production of tuberose plants. Tishreen University Journal for Research and Scientific Studies - Biological Sciences Series, 14(5):51-66.

Nikee, E.; Pazoki, A. and Zahedi, H. (2014). Influence of ascorbic acid and gibbrellin on alleviation of salt stress in summer savory (Satureja hortensis, L.). Int. J. Bio. Sci., 5(4): 245-255.

Page, A.L.; Miller, R.H. and Keeney, D.R. (1982). Methods of soil analysis; 2. Chemical and Microbiological Properties, American Soc. of Agronomy, Madison, Wisconsin, USA, 1159 p. 
Pal, V.; Ram, M. and Kumar, M. (2015). Effect of various levels of spacing and salicylic acid treatment on vegetative growth and flowering of gladiolus (Gladiolus grandiflora, L.) cv. White prosperity. South Asian J. Food Technol. Environ., 1(1):101-104.

Pandey, S.K.; Kumari, S.; Singh, D.; Singh, V.K. and Prasad, V.M. (2017). Effect of biofertilizers and organic manures on plant growth, flowering and tuber production of dahlia (Dahlia variabilis, L.) cv. S.P. Kamala. Int. J. Pure App. Biosci., 5(2):549-555.

Parmar, S.; Patel, R.B.; Chawla, S.L.; Bhatt, D. and Patel, K. (2017). Effect of chemical and bio-fertilizers on growth and flowering of golden rod (Solidago canadensis, L.) cv. "Local". International Journal of Chemical Studies, 5(5):104108.

Pattnaik, S. (2016). Effect of Organic Manures on Growth and Flowering of Tuberose (Polianthes tuberosa) cv. Phule Rajani. M.Sc. Thesis, Orissa University of Agriculture and Technology, India, $83 \mathrm{p}$.

Pawar, A.; Chopde, N. and Nikam, B. (2018). Effect of thiourea and salicylic acid on growth, flowering and yield of gladiolus. International Journal of Chemical Studies, 6(4):2104-2106.

Prasad, L.; Saravanan, S.; Lall, D. and Singh, V.K. (2017). Effect of organic manure and inorganic fertilizer on plant growth and flower yield of Asiatic lily (Lilium longiflorum) sp. Zephyranthes. Environment \& Ecology J., 35 (2A): 929932.

Priyakumari, I. and Sheela, V.L. (2005). Micropropagation of gladiolus cv. 'Peach blossom' through enhanced released of axillary buds. Journal of Tropical Agriculture, 43(1-2):47-50.

Ramtin, A.; Kalatejari, S.; Naderi, R. and Matinizadeh, M. (2016). Effect of preharvest foliar application of benzyl adenine and salicylic acid on carnation cv. Spray and Standard. Biological Forum, an International Journal, 7(2): 955-958.

Rashid, M.H. (2018). Effect of corm size and growth regulators on growth, flowering and quality of gladiolus (Gladiolus grandiflorus L.). Fundamental and Applied Agriculture, 3(3):596-601.

Reddy, A.G. and Sarkar, M.M. (2016). Studies on the effect of foliar application of calcium on post-harvest, corm and cormel production in gladiolus cV. Summer Sunshine. Int. J. Agric Environ. Biotechnol., 9(1):89-94.

Roy, S.; Fatmi, U.; Mishra, S. and Singh, R. (2017). Effect of preplant soaking of corms in growth regulators on sprouting, vegetative growth and corm formation in gladiolus (Gladiolus grandiflorus L.). J. Pharmacognosy Phytochem, 6:11351138.

Saeed, T.; Hassan, I.; Jilani, G. and Abbasi, N.A. (2013). Zinc augments the growth and floral attributes of gladiolus, and alleviates oxidative stress in cut flowers. Sci. Hort., 164:124-129. https://doi.org/10.1016/j.scienta.2013.09. 017.

Sarkar, M.A.H.; Hossain, M.I.; Uddin, A.F.M.J.; Uddin, M.A.N. and Sarkar, M.D. (2014). Vegetative, floral and yield attributes of gladiolus in response to gibberellic acid and corm size. Scientia Agric., 3:142-146. https://doi.org/10. 15192/PSCP.SA.2014.3.3.142146

Sathyanarayana, E.; Patil, S.; Bahubali, M. and Chawla, S.L. (2018). Effect of INM on gladiolus (Gladiolus grandiflorus, L.) cv. American Beauty under Navsari and Tansa Conditions. Int. J. Pure App. Biosci., 6(4):48-55.

Sisodia, A.; Singh, A.K.; Padhi, M. and Hembrom, R. (2020). Flower Crop Response to Biotic and Abiotic Stresses. In: Rakshit, A.; Singh, H.; Singh, A.; Singh, U. and Fraceto, L. (eds.), New 


\section{A.A. Hassan and M.M. Abd El-Azeim}

Frontiers in Stress Management for Durable Agriculture, Springer, Singapore, pp. 477-491.

Sönmez, F.; Cig, A.; Gülser, F. and Basdogan, G. (2013). The effects of some organic fertilizers on nutrient contents in hybrid Gladiolus. Eurasian Journal of Soil Science, 2:140-144.

Sorial, M.E.; El-Kateeb, S.R. and Ali, F.A. (1992). Synergistic effect of Azotobacter on the growth and $\mathrm{N}, \mathrm{P}$ and $\mathrm{K}$ contents of tomato. Menufeya J. Agric. Res., 17(14): 1999-2014.

Srivastava, R and Govil, M. (2005). Influence of biofertilizers on growth and flowering and yield in Gladiolus cv. American Beauty. Proc. of the International Conference and Exhibition on Soilless Culture, Singapor, ActaHort, 742:183-188.

Srivastava, R.; Preetham, S.P. and Chand, S. (2014). Effect of organic manures and biofertilizers on vegetative, floral and post-harvest attributes in tuberose (Polianthes tuberosa) var. Shringar. Asian J. Biol. Life Sci., 3(1):6-9.
Suseela, T.; Chandrasekha, R.; Vijaya, V.; Bhaskar, D.R.; Suneetha, S. and Umakrishna, K. (2016). Effect of organic manures, inorganic fertilizers and micronutrients on vegetative and floral characters of tuberose (Polianthes tuberosa, L.) cv. 'Suvasini'. International Journal of Scientific and Research Publications, 6(2):170-173.

Taha, R.A. and Hassan, A.H. (2008). Response of gladiolus plants to mineral fertilization and bio-fertilization treatments. 2- Corm production and chemical constituents. Alex. J. Agric. Res., 53:87-95.

Wilde, S.A.; Covey, R.P.; Lyer, J.C. and Voigt, G.K. (1985). Soil and Plant Analysis for Tree Culture. Oxford, IBH. Publishing Co., New Delhi, India, 224 p.

Zaghloul, M.A.R. and Moghazy, E.I. (2001). Response of some gladiolus cultivars to organic manure and NPK fertilizers in sandy soil under Sinai conditions. Annals Agric. Sci., Moshtohor, 39(1):585-602.

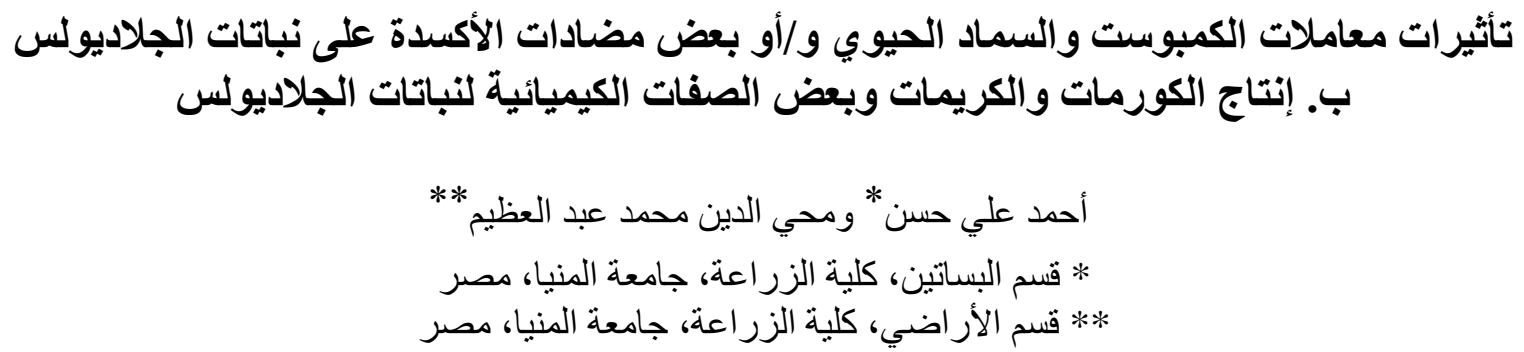

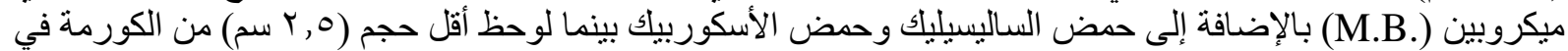

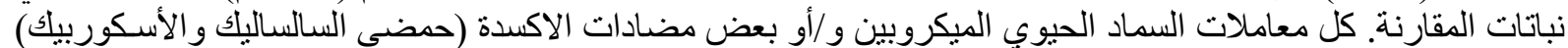

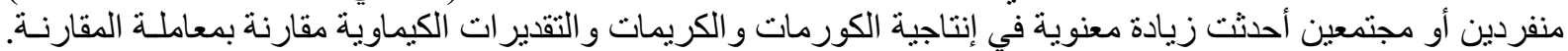
معاملات خليط من السماد الحيوي (الميكروبين) + حمض السيالين السياليك + حمض الأسكوربيك (فيتامين ج) كانت أكثر فاعليـة 


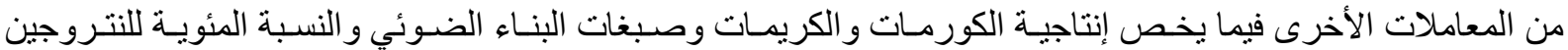

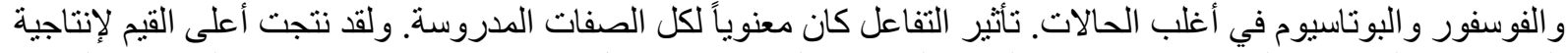

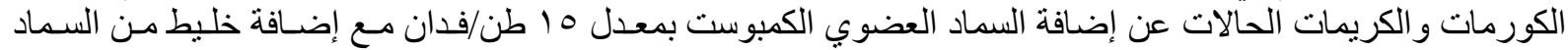

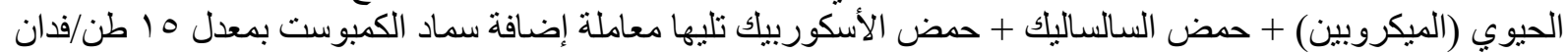

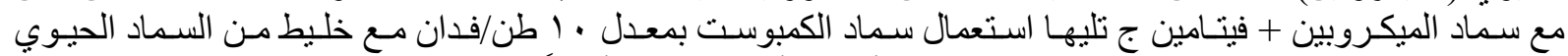

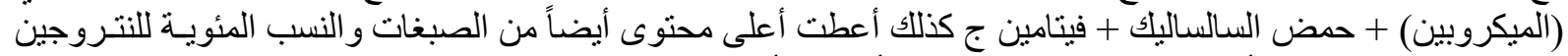

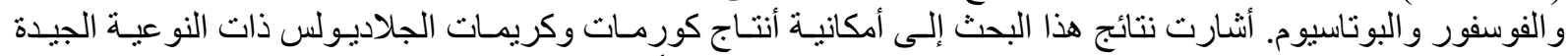

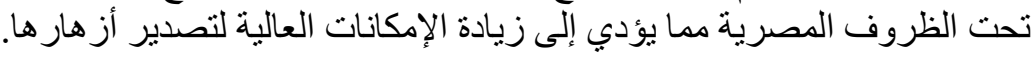

